\title{
Mineral Geochemistry of Basaltic Rocks from IODP Expeditions 334 and 344: Implications for Magmatic Processes of Cocos Ridge Segment Being Subducted Beneath the Middle America Trench
}

\author{
Quanshu Yan ${ }^{1,2, *}$ and Zhenmin Ge ${ }^{1}$ \\ 1 Key Laboratory of Marine Geology and Metallogeny, First Institute of Oceanography, \\ Ministry of Natural Resources, Qingdao 266061, China; gezhenmin1993@163.com \\ 2 Laboratory for Marine Geology, Qingdao National Laboratory for Marine Science and Technology, \\ Qingdao 266061, China \\ * Correspondence: qsyan@fio.org.cn; Tel.: +86-532-88967011
}

check for updates

Citation: Yan, Q.; Ge, Z. Mineral Geochemistry of Basaltic Rocks from IODP Expeditions 334 and 344:

Implications for Magmatic Processes of Cocos Ridge Segment Being Subducted Beneath the Middle America Trench. Minerals 2021, 11, 769. https://doi.org/10.3390/ $\min 11070769$

Academic Editor: Jan C. M. De Hoog

Received: 4 June 2021

Accepted: 8 July 2021

Published: 16 July 2021

Publisher's Note: MDPI stays neutral with regard to jurisdictional claims in published maps and institutional affiliations.

Copyright: (C) 2021 by the authors. Licensee MDPI, Basel, Switzerland. This article is an open access article distributed under the terms and conditions of the Creative Commons Attribution (CC BY) license (https:// creativecommons.org/licenses/by/ $4.0 /)$.

\begin{abstract}
The Cocos Ridge, which is subducted beneath the Central American Volcanic Arc, has a complex tectonic evolution history due to plume-ridge interaction between the Galápagos plume and the Cocos-Nazca spreading center. This study presents major and trace element analyses of plagioclase and clinopyroxenes hosted by Cocos Ridge basaltic rocks that were drilled in three holes (U1381A, U1381C and U1414A) of Sites U1381 and U1414 on the Cocos Ridge close to the Middle America Trench during the Integrated Ocean Drilling Program (IODP) Expeditions 334 and 344 . The results show that (1) plagioclases are mainly bytownite and labradorite with subordinate andesine, which are enriched in light rare earth elements (LREE) and some large-ion lithophile elements (LILE) and exhibit marked positive Eu anomalies; and (2) that clinopyroxenes are augites, which are depleted in highly incompatible elements such as LREE and LILE, have nearly flat heavy rare earth elements patterns (HREE) and lack Eu anomalies in chondrite-normalized rare earth element (REE) diagrams. During the ascent to the surface, the primary magmas experienced fractional crystallization of plagioclase, clinopyroxene, Ti-Fe oxides and possibly olivine (complete replacement of olivine by secondary minerals). The crystallization temperatures of plagioclase phenocrysts and microlites are 1050 to $1269^{\circ} \mathrm{C}$, and 866 to $1038^{\circ} \mathrm{C}$, respectively, and the pressures of plagioclase phenocrysts are 0.3-0.7 GPa. The crystallization temperatures of clinopyroxene phenocrysts/micro-phenocrysts is $1174-1268^{\circ} \mathrm{C}$, similar to those of plagioclase phenocrysts, suggesting some of clinopyroxene and plagioclase phenocrysts cotectic crystallized during early stage of magmatic evolution. In addition, the equilibrium pressures of clinopyroxene phenocrysts/micro phenocrysts are 0.02-0.97 GPa, implying that the clinopyroxene started to crystallize within the mantle, and magma evolution has undergone an early crystallization stage with clinopyroxene and no plagioclase.
\end{abstract}

Keywords: basaltic rocks; plagioclase; clinopyroxene; mineral geochemistry; magmatic processes; Cocos Ridge

\section{Introduction}

Seamount chains and/or aseismic ridges (e.g., Hawaii-Emperor chain) generally represent the surface expression of a long-lived hotspot activity as the tectonic plate moves over a relatively stationary mantle plume [1]. Moreover, aseismic ridges near mid-oceanic spreading centers may have relatively complex magmatic histories due to the plume-ridge interactions. In the eastern Pacific region, the Cocos Ridge on the Cocos plate is generally interpreted as an aseismic ridge, which was formed as the stationary Galápagos hot spot affected the NE moving Cocos plate and interacted with the Cocos-Nazca spreading center [2-4]. 
The lavas from the Galápagos archipelago display complex geochemical spatial zonation, with relatively enriched, hotspot-like signatures in the west and at the southern periphery, and depleted signatures in the central and northern regions facing the east $[5,6]$. Various processes were proposed to explain the origin of this geochemical spatial zonation. Some scientists argued for the existence of a mantle plume [6-8]. Hoernle et al. [9] suggested that the Galápagos mantle is inherently compositionally zoned. Gibson and Geist [10] suggested that the variations in lithospheric thickness may control the melting of a heterogeneous mantle and thereby cause regional geochemical variations in the composition of the erupted lavas in the Galápagos archipelago. Similar to the Hawaiian plume, the Galápagos plume could also be a bilaterally asymmetric plume [11]. In addition, the Galápagos mantle plume could have persisted for $95 \mathrm{Ma}$ [12].

The Cocos Ridge, formed by the interaction of Galápagos hot spot and Cocos-Nazca spreading center, is currently subducted northeastward under the Caribbean plate along the Middle America Trench [13] (Figure 1a). Until now, many studies have focused on dredged lavas samples from this ridge [14,15], and inferred a long-lived source heterogeneity of the Galápagos plume source [16,17], and complex spatial isotopic zonation in the Galápagos plume for at least $14 \mathrm{Ma}$ [9]. However, studies of mineral composition from the Cocos Ridge basalts are scarce, which hinders understanding the magmatic process of the ridge and the evolution of the Galápagos hot spot.
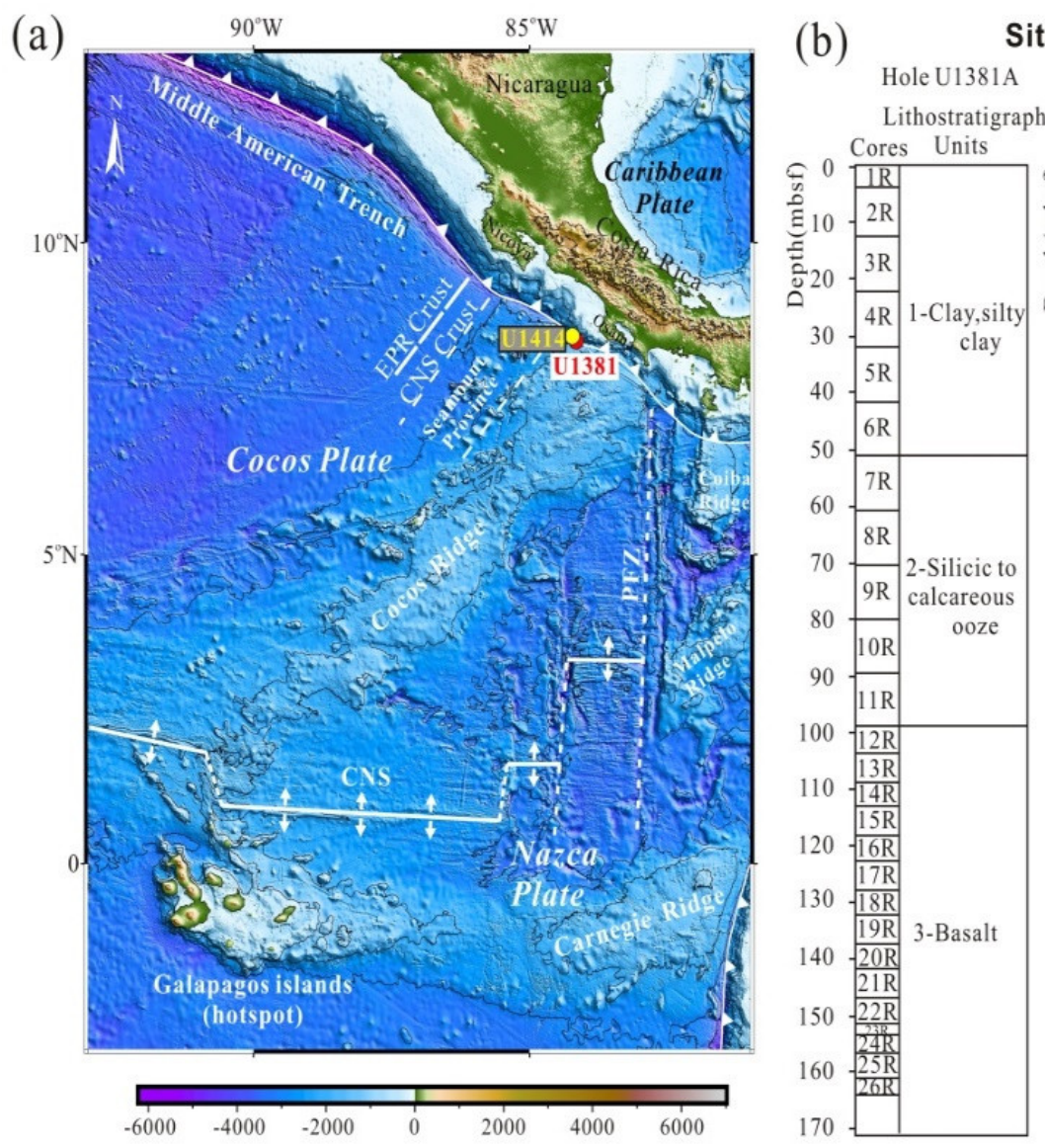

Site U1381

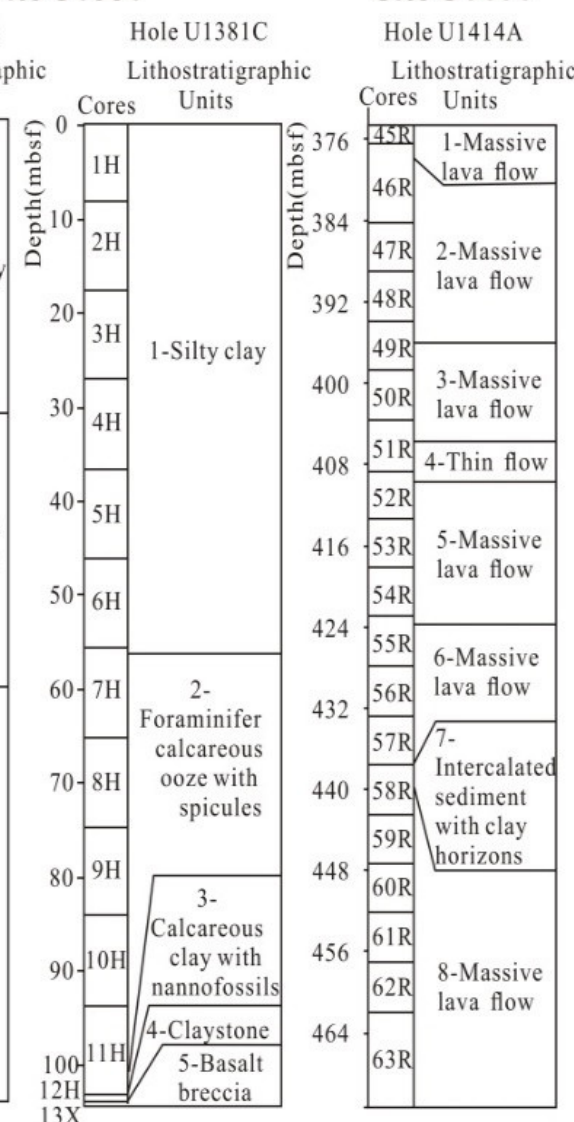

Figure 1. (a) Sketch geological map of the Cocos Ridge and the adjacent regions, showing locations of IODP Sites U1381 and U1414 [19-21]. EPR-Eastern Pacific Rise; CNS Cocos-Nazca spreading center; PFZ-Panama fracture zone. (b) Schematic lithostratigraphic summary of holes U1381A, U1381C and U1414A (mbsf: meter below seafloor) [19-21]. Of studied samples, five samples (334-U1381A-14R-2-W 136/139, 334-U1381A-16R-2-W 134/137, 334-U1381A-18R-2-W 1/4, 334-U1381A-20R-2W 115/118, and 334-U1381A-26R-1-W 80/83) are from hole U1381A, and one sample (344-U1381C-13X-1-W 11/16) is from hole U1381C, and six samples (344-U1414A-46R-1-W 107/110, 344-U1414A-48R-1-W 117/122, 344-U1414A-51R-4-W 126/134, 344-U1414A-56R-1-W 109/115, 344-U1414A-59R-2-W 82/87 and 344-U1414A-60R-2-W 55/65) are from hole U1414A. 
During the Integrated Ocean Drilling Program (IODP) Expeditions 334 and 344, the Cocos Ridge basement basalts were recovered at Sites U1381 and U1414 (Figure 1). Yan and Shi [18] presented a data report for the bulk rock major and trace element and Sr$\mathrm{Nd}-\mathrm{Pb}$ isotope compositions of basaltic rocks at Sites U1381 and U1414. In this study, we carried out in situ major and trace element analyses for plagioclase and clinopyroxene hosted by the basaltic rock samples obtained from Holes U1381A and U1381C and Hole U1414A (Figure 1). These data, combined with bulk rock compositions of host basaltic rocks, are used to decipher magmatic processes for the Cocos Ridge segment near the Middle America Trench.

\section{Geological Setting and Sample Description}

The submarine Cocos Ridge is a bathymetric high of more than $1000 \mathrm{~km}$ length and 250-500 km width, that raises about $2000 \mathrm{~m}$ above than the adjacent seafloor $[4,19,20]$ (Figure 1a). The ridge is oriented NE-SW parallel to the recent motion of Cocos Plate, and extends from the Cocos-Nazca spreading center north of Galápagos Platform to the Middle America Trench off the southwest coast of Costa Rica (Figure 1a). In the central part of the Cocos Ridge, the Moho is located about $21 \mathrm{~km}$ depth, and the thickened lower crust reaches about three times the average thickness of normal oceanic lower crust [4]. There are numerous seamounts on the oceanic crust to the northwest of the Cocos Ridge [4] (Figure 1a).

The submarine lavas from the Cocos Ridge are exclusively tholeiitic basalts, whereas those from the seamounts northwest of the Ridge are dominated by alkali basalts, and tholeiitic basalts are subordinate in the seamounts [14]. Most lavas from these seamounts were inferred to be the products of small degree melts of the Galápagos mantle plume source rocks, and which were erupted after the migration of the Cocos-Nazca Spreading Center $[14,15]$. The lavas from Cocos Ridge are slightly enriched in rare earth elements (REEs) and incompatible elements, as is typical for enriched MORB $[2,8,11,14,15,18]$. Some characteristic bulk-rock trace element ratios (e.g., $\mathrm{Nb} / \mathrm{U}, \mathrm{Ce} / \mathrm{Pb}$ ) for basaltic rocks from the Cocos ridge $[15,18]$ are similar to those found in basalts from the Galápagos archipelago [11].

IODP Sites U1381 and U1414 are located on the Cocos Ridge segment of incoming plate (Figure 1a). Site U1381 is $\sim 4.5 \mathrm{~km}$ seaward of the deformation front offshore Osa Peninsula in Costa Rica, while Site U1414 is located $\sim 1 \mathrm{~km}$ seaward from the Osa Peninsula [21] (Figure 1a). Basaltic basement was recovered from three holes (U1381A, U1381C and U1414A) at these two sites (Figure 1b, Supplementary Table S1). The detailed drilling information is given in Supplementary Table S1 and a lithostratigraphic summary is shown in Figure 1b. The ages for the Cocos Ridge segment close to the Middle America Trench are 13.0-14.5 Ma [2,14,22], and those of Cocos Ridge basement basaltic rocks drilled during IODP expeditions 334 and 344 were constrained to be 14 Ma by paleomagnetic data [23].

These studied rock samples are tholeiitic basalts and show trace element characteristics of enriched mid-ocean ridge basalts (E-MORB) [18]. The detailed petrographic descriptions for these samples has been provided in [19-21]. Petrographic studies showed that groundmass alteration is ubiquitous in almost all samples, with partial replacement of plagioclase and clinopyroxene and complete replacement of olivine by secondary minerals. The samples also contain some opaque minerals (e.g., Fe-Ti oxides) [19-21]. Therefore, we focused on plagioclase and clinopyroxene phenocrysts and microlites/micro-phenocrysts in this study. The plagioclase phenocrysts are mostly euhedral and subhedral, with grain size of $0.15 \mathrm{~mm} \times 0.35 \mathrm{~mm}$ to $0.70 \mathrm{~mm} \times 1.05 \mathrm{~mm}$ (Figure 2). The clinopyroxene phenocrysts are mostly subhedral and are usually smaller than plagioclases, with grain size of $0.20 \mathrm{~mm}$ to $1.0 \mathrm{~mm}$. Some clinopyroxene and plagioclase phenocrysts cluster together and have glomerophyric textures (Figure 2d,e). Plagioclase microlites (with grain size of $0.01 \mathrm{~mm} \times 0.05 \mathrm{~mm}-0.1 \mathrm{~mm} \times 0.1 \mathrm{~mm}$ ) and clinopyroxene micro-phenocrysts (with grain size of 0.01-0.2 mm) occur in most samples (Figure 2). Some plagioclase phenocrysts (e.g., phenocryst no. pl-02 in sample 334-U1381A-14R-2-W 136/139) show resorption textures (Figure 2a). 


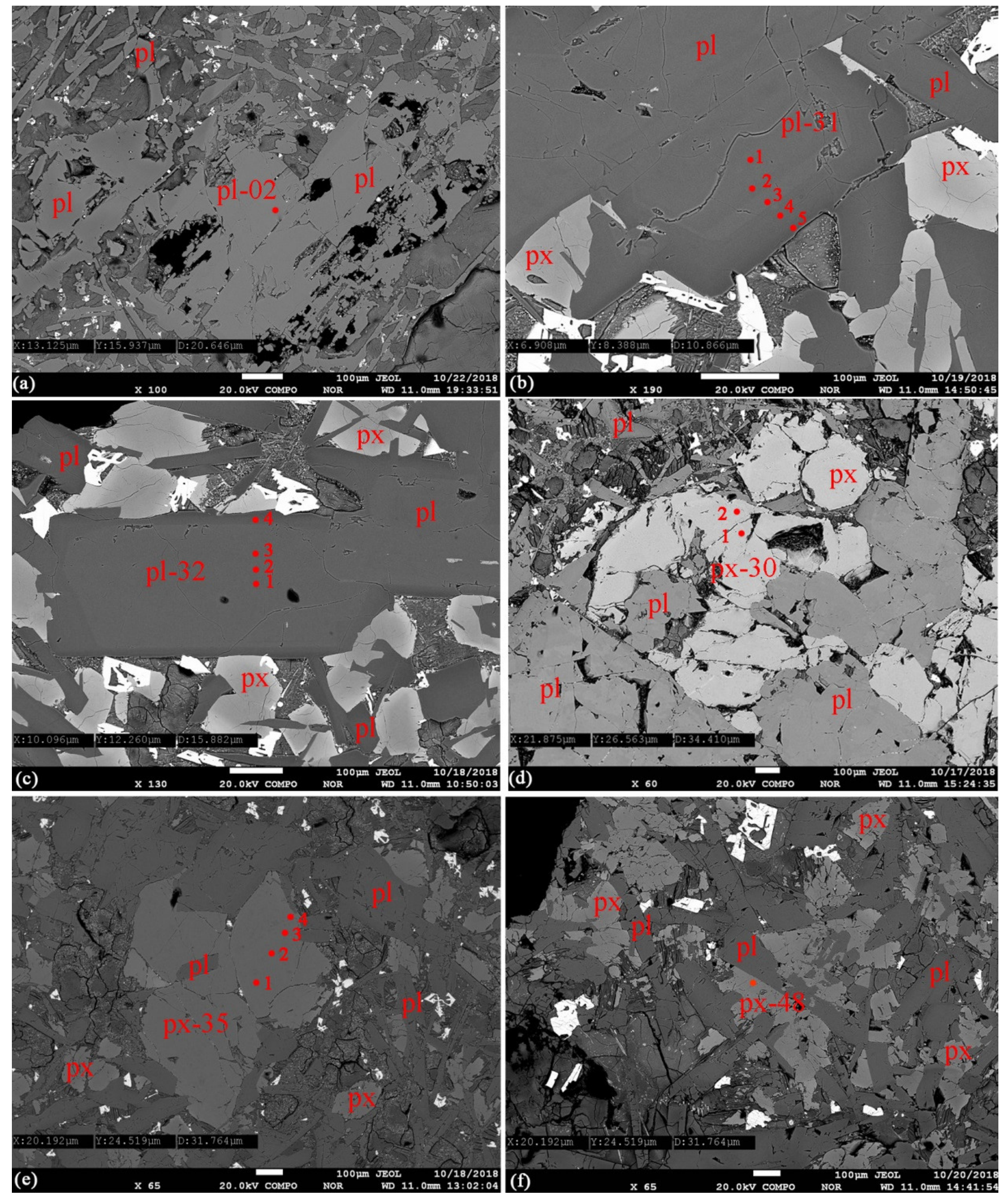

Figure 2. Representative backscattering electron (BSE) images of plagioclases and clinopyroxenes. The red dots are electron probe test points (pl: plagioclase; px: pyroxene). (a) sample 334-U1381A-14R-2-W 136/139; (b,c) sample 344U1414A-46R-1-W 107/110; (d) sample 344-U1414A-51R-4-W 126/134; (e) sample 344-U1414A-56R-1-W 109/115; (f) sample 344-U1414A-60R-2-W 55/65. 


\section{Methods}

In situ major- and trace elements of plagioclases and clinopyroxenes hosted by basement basaltic rocks samples from Sites U1381 and U1414 were analyzed by electron probe micro-analyzer (EPMA) and laser ablation inductively coupled plasma mass spectrometry (LA-ICP-MS), respectively. The analytical procedures are as follows.

EPMA analysis was performed at the Key Laboratory of Marine Geology and Metallogeny, First Institute of Oceanography, Ministry of Natural Resources (Qingdao, China) with a JXA-8230 electronic probe analyzer manufactured by JEOL Co., Ltd. (Tokyo, Japan) The following conditions were used to analyze the minerals: acceleration voltage of $15.0 \mathrm{kV}$, sample current of $1 \times 10^{-8} \mathrm{~A}$, and an electron beam spot diameter of $1 \mu \mathrm{m}$. The standards used in these analyses were albite for $\mathrm{Na}$ and $\mathrm{Si}$; orthoclase for $\mathrm{K}$; diopside for $\mathrm{Ca}$; olivine for $\mathrm{Mg}$; hematite for $\mathrm{Fe}$; garnet for $\mathrm{Al}$; chromium oxide for $\mathrm{Cr}$; rutile for $\mathrm{Ti}$; rhodonite for $\mathrm{Mn}$; and nickel silicide for Ni. The analytical results were corrected by the ZAF method ( $Z$, $A$ and $F$ represent atomic number, absorption and fluorescence, respectively). The quantitative detection limit for element concentration was about $100 \mathrm{ppm}$. The precision of major oxide $\left(\mathrm{SiO}_{2}, \mathrm{Al}_{2} \mathrm{O}_{3}\right.$ and $\left.\mathrm{CaO}\right)$ analyses was better than $1 \%$, and that of minor element $\left(\mathrm{Na}_{2} \mathrm{O}\right.$, $\mathrm{K}_{2} \mathrm{O}, \mathrm{TiO}_{2}, \mathrm{P}_{2} \mathrm{O}_{5}, \mathrm{MnO}, \mathrm{Cr}_{2} \mathrm{O}_{3}$, and $\mathrm{MgO}$ ) analyses was better than 5\%. Backscattering electron (BSE) images for typical minerals were obtained by EPMA (Figure 2).

The LA-ICP-MS analyses were performed at Beijing Createch Testing International Co. Ltd. (Beijing, China). TA ESI NWR 193 nm excimer laser system was used, together with a Plasma Quant MS inductively coupled plasma mass spectrometer (Analytik Jena, Jena, Germany). In the laser ablation process, helium was used as the carrier gas for ablation. Laser beam spot diameter was $35 \mu \mathrm{m}$, and the ablation frequency is $10 \mathrm{~Hz}$. The single-point analysis time is $80 \mathrm{~s}$, including $15 \mathrm{~s}$ blank background acquisition, $45 \mathrm{~s}$ continuous ablation collection, and $20 \mathrm{~s}$ cleaning injection system. The reference material used for plagioclase analysis was SRM 612, and those for clinopyroxene analysis were BIR-1G and SRM 612. The data were processed by the Glitter software using the internal standard method, with $\mathrm{Si}$ as the internal standard element. The analysis of most of the elements had an accuracy of less than $5 \%$ and a precision of greater than $10 \%$.

\section{Results}

\subsection{Plagioclase}

\subsubsection{Major Elements}

Data for major oxides of plagioclases hosted by basaltic rock samples from Sites U1381 and U1414 are presented in Supplementary Table S2. The plagioclase are mainly bytownite and labradorite, and minor andesine, and there are no obvious differences in plagioclase compositions between these two drilling sites (Supplementary Table S2, Figure 3). The An value $[\mathrm{Ca} /(\mathrm{Ca}+\mathrm{Na}+\mathrm{K}) \times 100]$ of plagioclase phenocrysts ranges from 42 to 89 , with an average value of 80 . Plagioclase phenocrysts are mostly bytownites, and only locally have rims of labradorite or andesine (Supplementary Table S2). Plagioclase microlites have An ranging from 41 to 74 , with an average value of 60. Plagioclase microlites are mostly labradorite, with subordinate bytownite and andesine (Supplementary Table S2). In a given rock sample, the An value of plagioclase phenocrysts are typically higher than those of plagioclase microlites (Figure 3). 

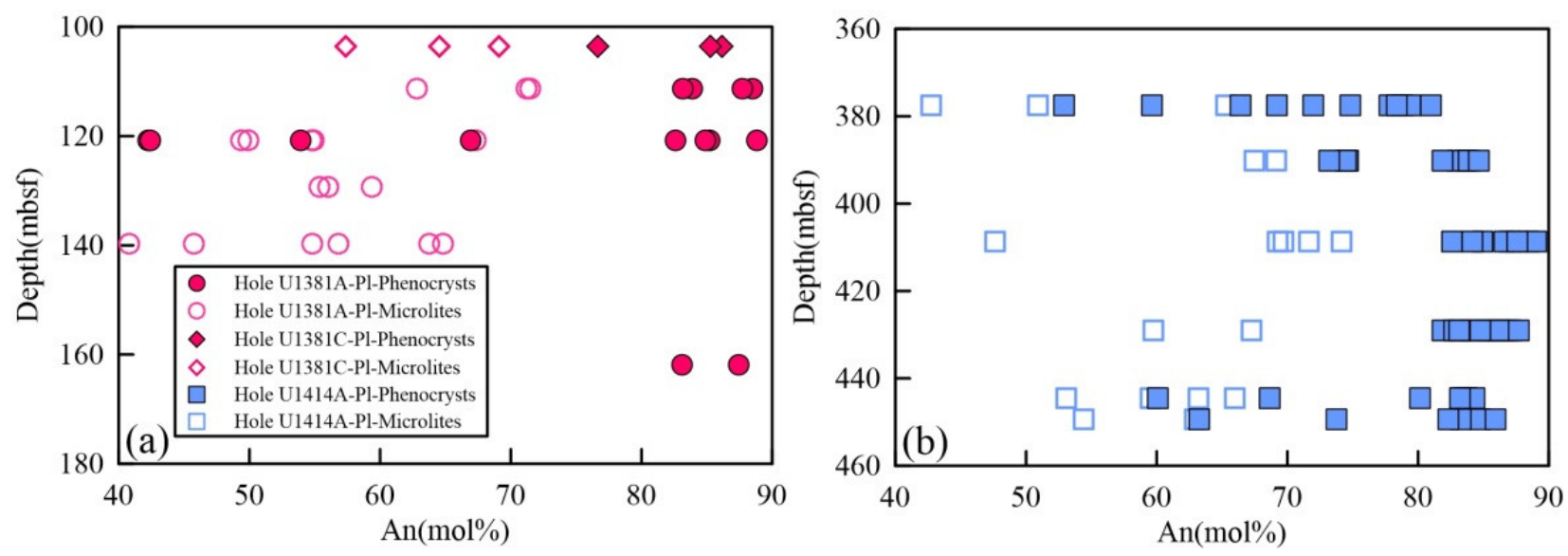

Figure 3. Downhole compositional variations of plagioclases in the basaltic rocks from Site U1381 (a) and Site U1414 (b).

Additionally, some plagioclase phenocrysts with high An value in the core and low An value in the rim (normally zoned) (e.g., phenocryst no. pl-32 in sample 344-U1414A46R-1-W 107/110) (Figure 2c, Supplementary Table S2). The largest plagioclase phenocrysts typically show oscillatory An zoning. For example, An of plagioclase phenocryst no. pl-31 in sample 344-U1414A-46R-1-W 107/110 (Figure 2b, Supplementary Table S2) are 78 to 79 at the core and then outwards decrease to 75, 69 and 53 in core-to-rim transect (Supplementary Table S2).

\subsubsection{Trace Elements}

Trace element data of plagioclases are presented in Supplementary Table S3. In general, trace element compositions of plagioclases from Site U1414 are similar to those from Site U1381 (Supplementary Table S3, Figure 4). The distributional patterns of all plagioclase phenocrysts are similar, and yet those of microlites show very different styles among different samples (Figure 4).

In this study, we analyzed the compositions of core to rim for eight plagioclase phenocrysts from eight rock samples (one phenocryst for each sample), and there didn't take on a consistent variation in trace element compositions from core to rim (Supplementary Table S3). In general, the plagioclase phenocrysts from Sites U1381 and U1414 are obviously enriched in light rare earth elements (LREE) and depleted in heavy rare earth elements (HREE) (Figure $4 \mathrm{a}, \mathrm{b}$ ), with $(\mathrm{La} / \mathrm{Yb})_{\mathrm{N}}$ (normalized to chondrite of [24]) ranging from 2.6 to 41.2 with an average value of $16.9(n=49)$ (Supplementary Table S3). The plagioclase phenocrysts from these two drill sites also have positive Eu anomalies (Figure $4 a, b$ ), and $\mathrm{Eu} / \mathrm{Eu}^{*}\left(\mathrm{Eu}^{*}\right.$ is calculated as the square root of $\left.\mathrm{Sm}_{\mathrm{N}} \times \mathrm{Gd}_{\mathrm{N}}\right)$ varies from 6.4 to 27.5 with an average of 13.8 (Supplementary Table S3). The plagioclase phenocrysts are enriched in large-ion lithophile elements (LILE, e.g., $\mathrm{Rb}, \mathrm{Sr}, \mathrm{Ba}$ ) and depleted in the high field strength elements (HFSE, e.g., $\mathrm{Zr}, \mathrm{Hf}, \mathrm{Nb}, \mathrm{Ta}$ ) in a primitive mantle-normalized multi-element diagram (Figure 4c,d). In contrast, the concentrations of total REE (TREE), Rb, Ba and $\mathrm{Nb}$ for most plagioclase microlites are slightly higher than that of plagioclase phenocrysts (Figure 4), and they have $(\mathrm{La} / \mathrm{Yb})_{\mathrm{N}}$ of 1.2-69.1 $(n=21)$ (average of 18.2) and $\mathrm{Eu} / \mathrm{Eu}^{*}$ of 3.5 to $33.3(n=21)$ (average of 15.6) (Supplementary Table S3). 

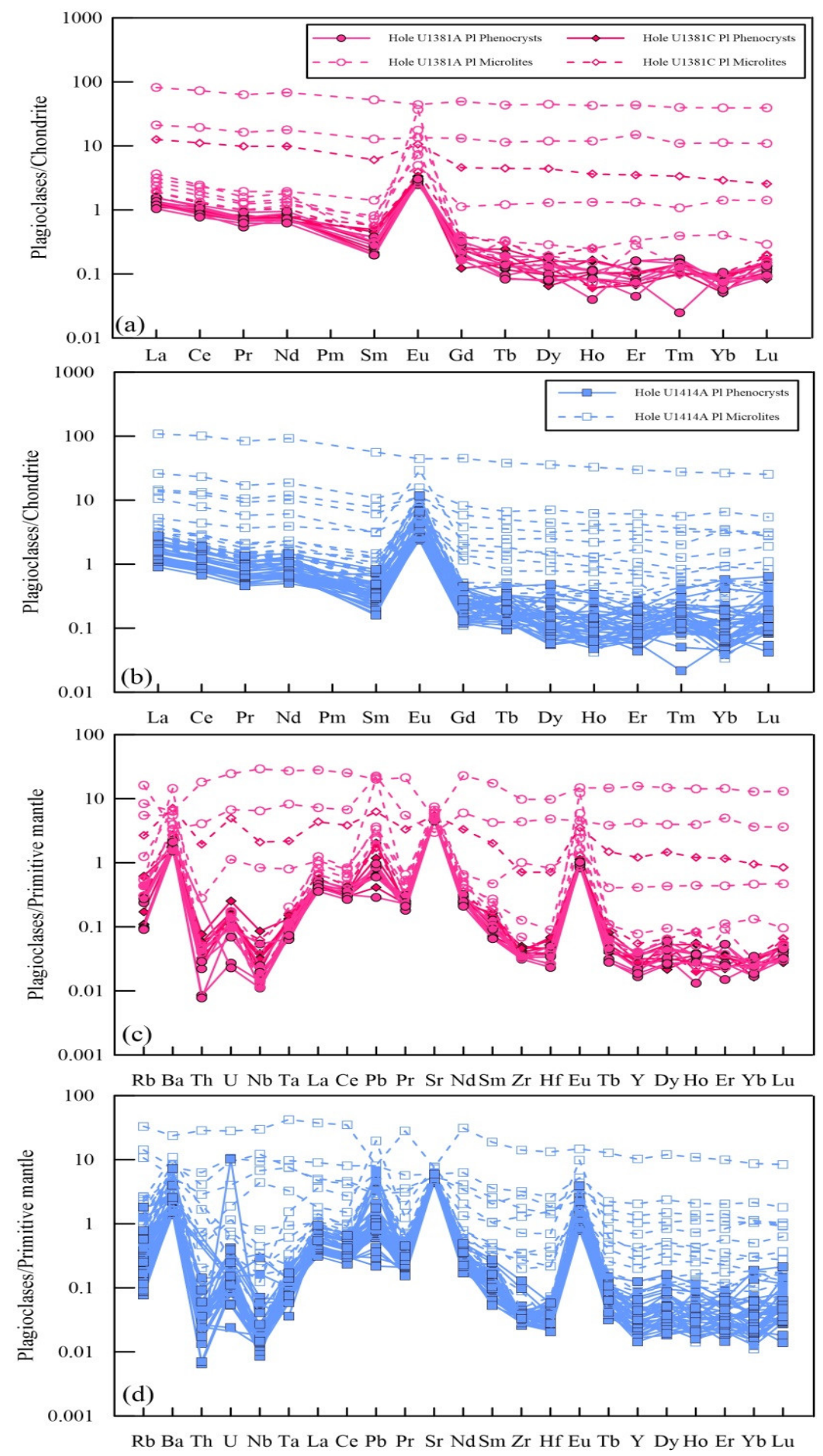

Figure 4. $\mathrm{C} 1$ chondrite-normalized rare-earth element (REE) distributional diagram for the plagioclases in basaltic rocks from Sites U1381 (a) and U1414 (b), and primitive mantle normalized trace element spider diagram for the plagioclases in basaltic rocks from Sites U1381 (c) and U1414 (d). Data for chondrite and primitive mantle are from [24].

\subsection{Clinopyroxene}

\subsubsection{Major Elements}

Data for major oxides of clinopyroxenes in basalts from Sites U1381 and U1414 are presented in Supplementary Table S4. The $\mathrm{SiO}_{2}$ content of all clinopyroxenes varies from $49.91 \mathrm{wt} \%$ to $54.67 \mathrm{wt} \%$. All analyzed clinopyroxenes belong to augites [25], and 
no obvious variations are observed from the core to the rim of phenocrysts (Supplementary Table S4). Generally, clinopyroxene phenocrysts have slightly higher $\mathrm{MgO}$ and $\mathrm{CaO}$ contents and lower $\mathrm{FeO}^{\mathrm{T}}$ contents than clinopyroxene micro-phenocrysts, and $\mathrm{Mg} \#$ $(\mathrm{Mg} \#=\mathrm{Mg} /(\mathrm{Mg}+\mathrm{Fe})(\mathrm{mol}))(0.72-0.80$, average of 0.77$)(n=22)$ of the former generally has higher than those $(0.49-0.79$, average of 0.68$)(n=48)$ of the latter (Supplementary Table S4). According to the Si-Al diagram of clinopyroxenes (Figure 5), most of the clinopyroxenes in this study plot in the field of phenocrysts of tholeiite basalts, which is consistent with the composition of their host rocks [18].

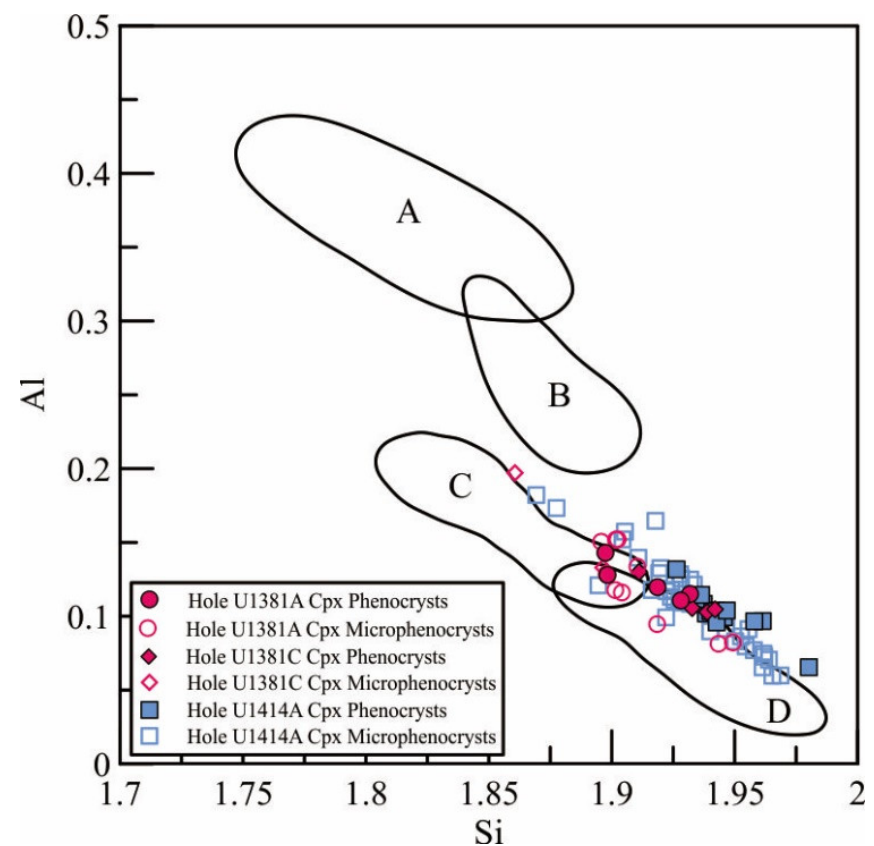

Figure 5. Si-Al diagram of clinopyroxenes. A-clinopyroxene megacrysts; B-clinopyroxene in cumulates; C-phenocryst in alkali basalts; D-phenocryst in tholeiitic basalts.

\subsubsection{Trace Elements}

The in-situ trace element data of clinopyroxenes are presented in Supplementary Table S5. In the chondrite-normalized REE diagrams and primitive mantle-normalized multi-element diagrams, the clinopyroxene phenocrysts and micro-phenocrysts have similar patterns. The TREE of microlites are slightly higher than those of the phenocrysts (Figure 6a,b; Supplementary Table S5). For example, $\mathrm{Yb}_{\mathrm{N}}$ of micro-phenocrysts (6.4-23.6, average of $11.2, n=29)$ are higher than those of phenocrysts (3.5-8.7, average of 4.9,n=22) (Figure 6a,b; Supplementary Table S5). The clinopyroxenes are depleted in LREE relative to HREE, and their HREEs show nearly flat patterns (Figure 6a). In particular, the $(\mathrm{La} / \mathrm{Yb})_{\mathrm{N}}$ ratios range from 0.13 to 0.37 with an average value of 0.27 (Supplementary Table S5). The clinopyroxenes show weak Eu negative anomalies (Figure 6a), with an average $\mathrm{Eu} / \mathrm{Eu}^{*}$ value of $0.90(0.73-1.06, n=51)$ and a $(\mathrm{Gd} / \mathrm{Eu})_{\mathrm{N}}$ of $1.21(0.97-1.44, n=51)$ (Supplementary Table S5). In primitive mantle-normalized multi-element diagrams (Figure 6b), most clinopyroxenes are depleted in highly incompatible elements (e.g., HFSE, Sr and Ba) relative to elements more compatible with clinopyroxene (e.g., HREE). Moreover, compared to samples from U1381, those from U1414 usually have relatively higher REEs, Rb, Ba, Th, Nb and Ta (Figure 6 and Supplementary Table S5), although samples from both of U1381 and U1414 show variations in element contents. 

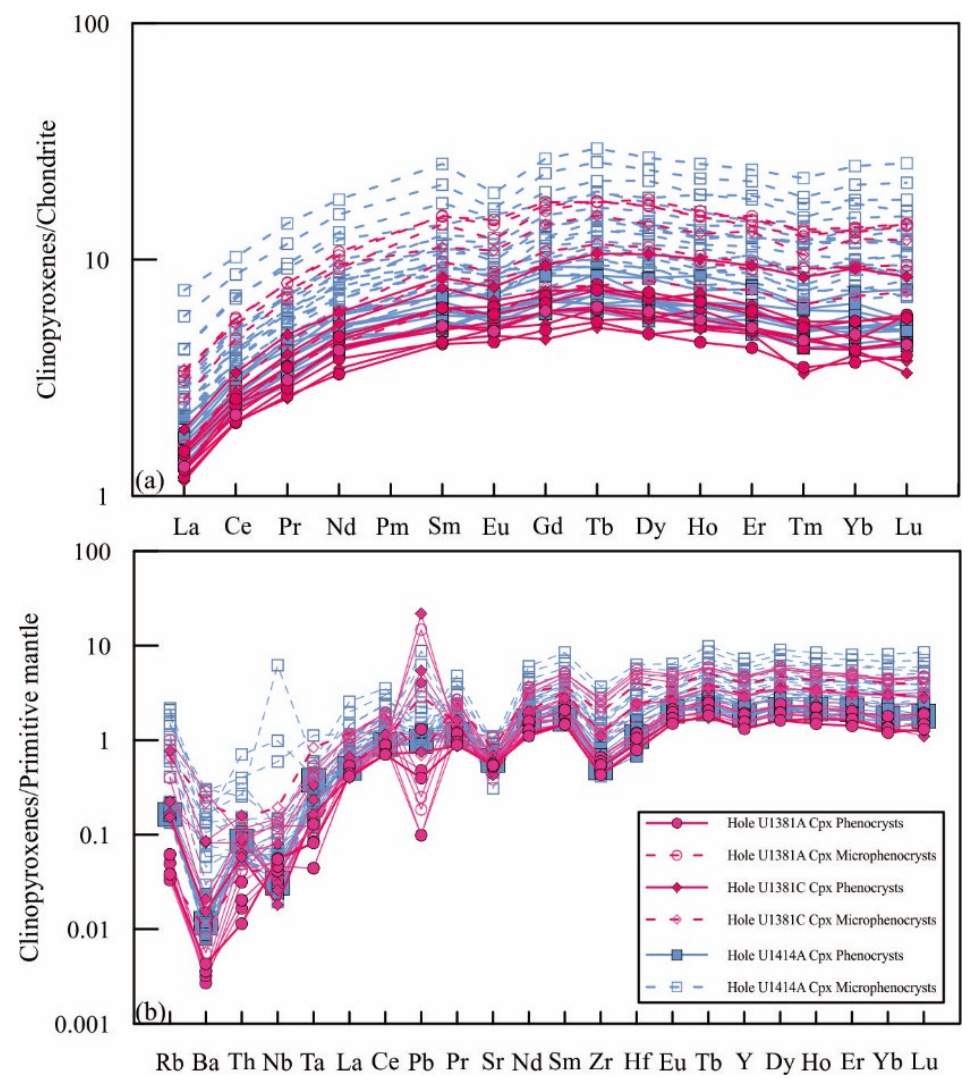

Figure 6. (a) chondrite-normalized REE distributional diagram and (b) primitive mantle normalized trace element spider diagram for the clinopyroxene in basaltic rocks from Site U1381 and U1414. Data for chondrite and primitive mantle are from [24].

\section{Discussion}

The lithology of the Galápagos mantle plume is still in debate, and magmatic processes related to the plume are not clear. Therefore, in this section we first summarize the nature of the mantle source and the degree of partial melting for the $14 \mathrm{Ma}$ Cocos ridge basalts by comparing them to modern Galápagos lavas. Then, we discuss the magmatic processes during the ascent of parental magma to the surface.

\subsection{Source Lithology and the Degree of Partial Melting}

Previous studies have shown that variations of geochemical compositions of Galapagos mantle plume result from mixing of different mantle source components [6-8]. Based on the interaction between the three Galápagos mantle end-members, DUM (depleted mantle component), PLUME (enriched mantle plume components) and FLO (an incompatible element-enriched, possibly metasomatically altered reservoir), a polybaric melting model based on rare earth element ratios to interpret the magmatic processes of Galápagos hotspot magmas (Figure 7) [8,15]. In particular, Harpp et al. [15] inferred that basaltic rocks from the Cocos Ridge axis were the product of $2 \sim 10 \%$ partial melting of a PLUME mantle source in the garnet stability field. In this study, by using the same melting model, we propose that basaltic lavas of Cocos Ridge from Sites U1381 and U1414 were produced by $1-5 \%$ melting of a PLUME mantle source. 


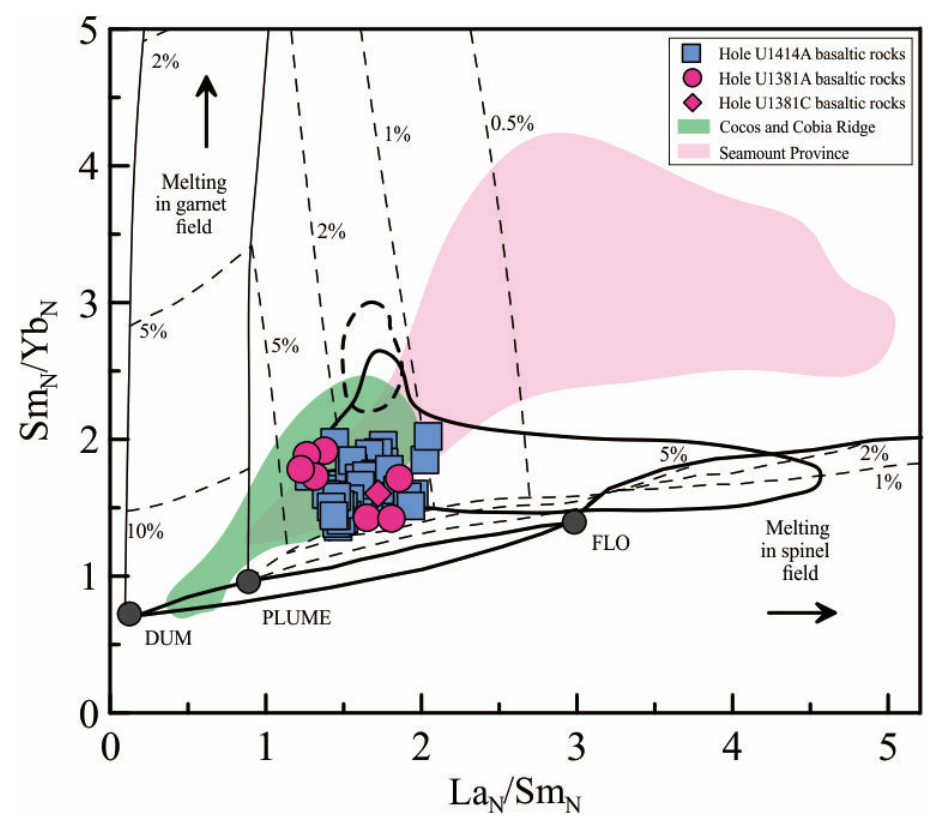

Figure 7. $\mathrm{La}_{\mathrm{N}} / \mathrm{Sm}_{\mathrm{N}}$ and $\mathrm{Sm}_{\mathrm{N}} / \mathrm{Yb}_{\mathrm{N}}$ for basaltic rocks from Sites U1381 and U1414 [15]. Four mantle components (isotopically) have been proposed by Harpp et al. [24], (1) the Center Domain reflecting the relative enriched mantle plume (PLUME); (2) the depleted upper mantle (DUM) in the Eastern Domain; (3) most enriched end-member in Southern Domain (FLO). Numerals close to the dashed lines represent the degree of partial melting (\%).The field with solid curve shows lavas from the Southwestern Galápagos including Floreana Island, and that with dashed outline shows lavas from Fernandina Island, Western Galápagos [24]. Data sources for whole-rock chemistry of basaltic rocks from Sites U1381 and U1414 are from Yan and Shi [18].

\subsection{Fractional Crystallization and Its Physical Conditions}

\subsubsection{Mineral Crystallization}

During ascent from the mantle source to the surface, primary magmas typically undergo fractional crystallization. The absence of olivine in the analyzed basaltic lavas may be due to cumulate formation in the early stages of magma evolution or post-emplacement replacement by secondary minerals. The sample suite selected in the present study show that clinopyroxene and plagioclase continuously crystallized from the evolving magmas, and hence the major and trace elements in these minerals continues to change, thereby providing an important record of the magmatic evolution. Except for a few clinopyroxene phenocrysts, the evolution trends of different elements in clinopyroxenes of the Cocos Ridge basement basalts are similar to those of the Galápagos basalts (data are from GeoROC database; http:/ / georoc.mpch-mainz.gwdg.de/georoc/ (accessed on 15 march 2020) (Figure 8). For example, with decreasing $\mathrm{Mg}^{\#} \mathrm{Cpx}, \mathrm{Cr}_{2} \mathrm{O}_{3}, \mathrm{SiO}_{2}$ and $\mathrm{CaO}$ decrease, and $\mathrm{TiO}_{2}$ increases (Figure 8a-e).

Trace element partition coefficients between clinopyroxene and melt $\left(\mathrm{Kd}_{\mathrm{cpx} / \text { melt }}\right)$ are controlled by a function of temperature, pressure and melt composition. Both $\mathrm{Cr}^{3+}$ and $\mathrm{Ti}^{4+}$ occupy the M1 site in clinopyroxene structure. Ti has smaller $\mathrm{Kd}_{\mathrm{cpx} / \text { melt }}$ relative to $\mathrm{Cr}$ and behaves incompatibly under various pressure conditions [26], whereas $\mathrm{Cr}$ is a highly compatible element in clinopyroxene $\left(\mathrm{Kd}_{\mathrm{Crcpx} / \mathrm{melt}} \sim 3.5\right.$ [27]). Therefore, $\mathrm{Cr}$ has a strong tendency to enter the clinopyroxene structure, while Ti prefers to remain in the residual melt. If no Ti-Fe oxide phases crystallize, the content of Ti in later-stage crystallized clinopyroxenes will increase. In the clinopyroxenes of basaltic rocks from Sites U1381 and U1414 that have $\mathrm{Mg}^{\#} \mathrm{Cpx}>0.68, \mathrm{Cr}$ decreases sharply and Ti increases with decreasing

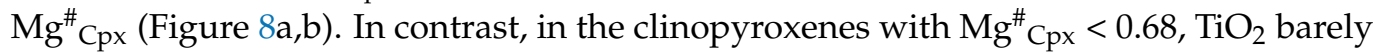
increases with decreasing $\mathrm{Mg}^{\#} \mathrm{Cpx}$ (Figure 8b), most likely in response to crystallization of Ti-Fe oxide phases. 

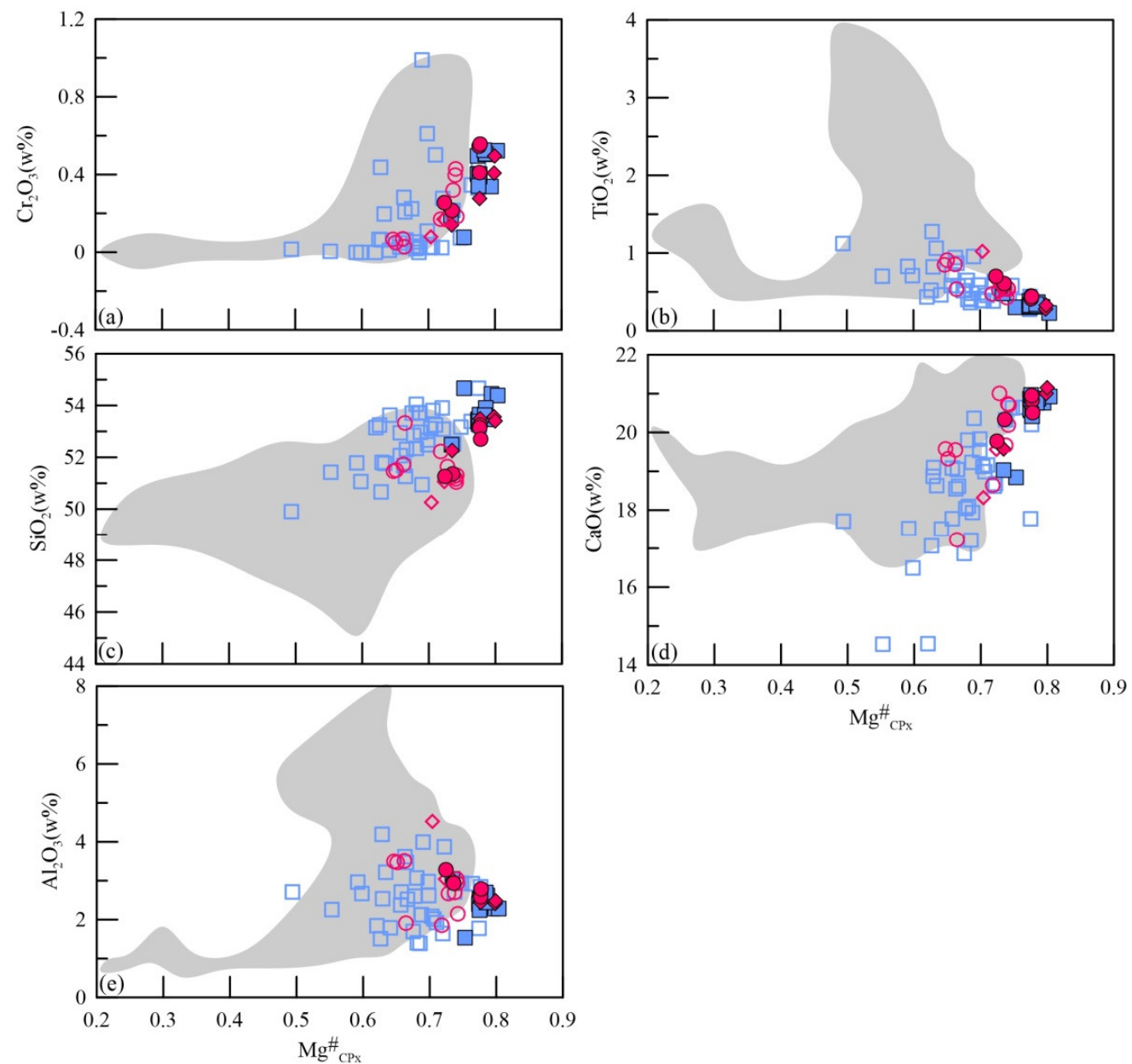

Figure 8. Plots of $\mathrm{Mg}^{\#} \mathrm{Cpx}$ versus major oxides of clinopyroxenes. $\mathrm{Mg}^{\#} \mathrm{Cpx}=\mathrm{Mg}^{2+} /\left(\mathrm{Mg}^{2+}+\mathrm{Fe}^{2+}\right)$. The shaded field shows data of clinopyroxenes from Galápagos Islands basalts (data are from GeoROC database, http:/ / georoc.mpch-mainz.gwdg.de/georoc/ (accessed on 15 march 2020). Symbols are the same as in Figure 5. (a) $\mathrm{Cr}_{2} \mathrm{O}_{3},\left(\right.$ b) $\mathrm{TiO}_{2}$, (c) $\mathrm{SiO}_{2}$, (d) $\mathrm{CaO}$ and (e) $\mathrm{Al}_{2} \mathrm{O}_{3}$ versus $\mathrm{Mg}^{\#} \mathrm{Cpx}$.

Previous studies have shown that plagioclase crystallization will reduce the $\mathrm{Al}_{2} \mathrm{O}_{3}$ content of host magma and later crystallizing clinopyroxene [28]. However, there is no correlation between $\mathrm{Al}_{2} \mathrm{O}_{3}$ and $\mathrm{Mg}^{\#} \mathrm{Cpx}$ in clinopyroxenes (Figure 8e), which could be caused by a balance between Al-rich plagioclase and Al-poor clinopyroxene in the fractionating mineral assemblage. Besides, Ca can only enter in the M2 crystallographic site in clinopyroxene, whereas $\mathrm{Mg}^{2+}$ and $\mathrm{Fe}^{2+}$ can occupy both M1 and M2 sites. Thus, the covariations of $\mathrm{CaO}$ content of clinopyroxenes with $\mathrm{Mg}^{\#} \mathrm{Cpx}$ may be mainly caused by the compositional variations of other elements in the M1co-site, such as $\mathrm{Cr}^{3+}$ and $\mathrm{Ti}^{4+}$ or $\mathrm{Al}^{4+}$. The $\mathrm{CaO}$ content decreases with decreasing $\mathrm{Mg}^{\#} \mathrm{Cpx}$ (Figure $8 \mathrm{~d}$ ), which suggests that plagioclase crystallization may reduce the $\mathrm{Al}^{4+}$ content in the $\mathrm{M} 1$ site, and more $\mathrm{Mg}$ and $\mathrm{Fe}^{2+}$ can enter the clinopyroxene relative to $\mathrm{Ca}$. However, the possibility that $\mathrm{Ca}$ decrease in clinopyroxene may be simply related to the cotectic crystallization of plagioclase and clinopyroxene in the evovling magmas because of both of these two minerals being Ca-rich, can not be ruled out.

From the above discussions, we inferred that the basement basalts of Cocos Ridge underwent fractional crystallization during the ascent of magma from source to surface. In order to identify the effect of mineral fractional crystallization on the magma compositions (Supplementary Table S8), we used the Petrolog3 software [29] to model the fractional crystallization and obtain the liquid line of descent (LLD) at the pressures of 1.0 GPa under an ideal fractional crystallization and anhydrous conditions, which represent the case 
for uppermost mantle where minerals begin to crystallize from magmas (Figure 9), and $\mathrm{Fe}_{2} \mathrm{O}_{3}$ in the melt was calculated using QFM buffer of oxygen fugacity. Because Sample 334-U1381A-26R-1-W 80/83 has highest MgO (11.5 wt\%) among studied samples [18], it was selected as the starting melt composition. The selected minerals involved in crystallization differentiation were olivine (ol), clinopyroxene (cpx), plagioclase ( $\mathrm{pl}$ ) and magnetite (mgt) (Supplementary Table S8). The results show that there is no obvious systematic compositional variations under different pressures. In general, with decreasing $\mathrm{MgO}$, the variations of $\mathrm{SiO}_{2}, \mathrm{TiO}_{2}, \mathrm{Al}_{2} \mathrm{O}_{3}, \mathrm{FeO}^{\mathrm{T}}$ and $\mathrm{CaO} / \mathrm{Al}_{2} \mathrm{O}_{3}$ basically follow a LLD. Some of major oxides, such as $\mathrm{CaO}, \mathrm{Na}_{2} \mathrm{O}$ and $\mathrm{K}_{2} \mathrm{O}$, deviate from the LLD, which may be due to the existence of small amounts of early crystallized crystal phases (clinopyroxene and plagioclase) in the Cocos ridge basaltic rocks. We concluded that fractional crystallization of crystals such as plagioclase, clinopyroxene and Ti-Fe oxide phases during the ascent of the parental magmas to the surface definitely affect the variation of some major and trace elements of the basaltic rocks from Cocos ridge.

\subsubsection{Physical Conditions of Crystallization}

Crystallization Temperatures and Pressures of Plagioclases

Temperature and pressure at which magma crystallizes is crucial to understanding magmatic processes [30-32]. In this study, the plagioclase microlites usually have lower An values (Figure 3) and higher incompatible element contents (Figure 4) than plagioclase phenocrysts, confirming that relative to microlites, the phenocrysts were crystallized from more primitive magmas at earlier times. In this study, the plagioclase thermometer of Mathez [30] was used to calculate the crystallization temperatures of plagioclases from Sites U1381 and U1414 (Table 1), and the whole rock compositions were used as melt compositions during calculation. In general, the crystallization temperatures of plagioclase phenocrysts range from 1050 to $1269^{\circ} \mathrm{C}$, which were slightly higher than those of the plagioclase microlites $\left(866-1038^{\circ} \mathrm{C}\right)$ (Table 1$)$. In detail, both of plagioclase phenocrysts and microlites from three holes (U1381A, U1381C and U1414A) show a ranges, $1050-1215^{\circ} \mathrm{C}$ (phenocrysts) versus $866-988^{\circ} \mathrm{C}$ (microlites) for hole U1381A, $1166-1242{ }^{\circ} \mathrm{C}$ (phenocrysts) versus $1021-1032{ }^{\circ} \mathrm{C}$ (microlites) for hole U1381C, and $1056-1269^{\circ} \mathrm{C}$ (phenocrysts) versus 971-1038 ${ }^{\circ} \mathrm{C}$ (microlites) for U1414A (Table 1). Moreover, the REE-in-plagioclase- clinopyroxene geothermometer [32] was also used to the crystallization temperatures for these plagioclase phenocrysts/microlites. The results showed that similar to those from the plagioclase thermometer of Mathez [30], for each hole the crystallization temperatures of plagioclase phenocrysts $\left(1177-1268^{\circ} \mathrm{C}\right)$ were slightly higher than those of the plagioclase microlites $\left(1047-1166^{\circ} \mathrm{C}\right)$ (Table 1). By comparing these two thermometers, the results from Sun and Liang [32] have less variations that those from Mathez [30] (Table 1), so the former may be more close to actual situation than the latter. It need to be noted that when using the REE-in-plagioclase- clinopyroxene geothermometer, different crystallization sequences of plagioclase and clinopyroxene may introduce significant errors in the calculated temperatures [32]. 

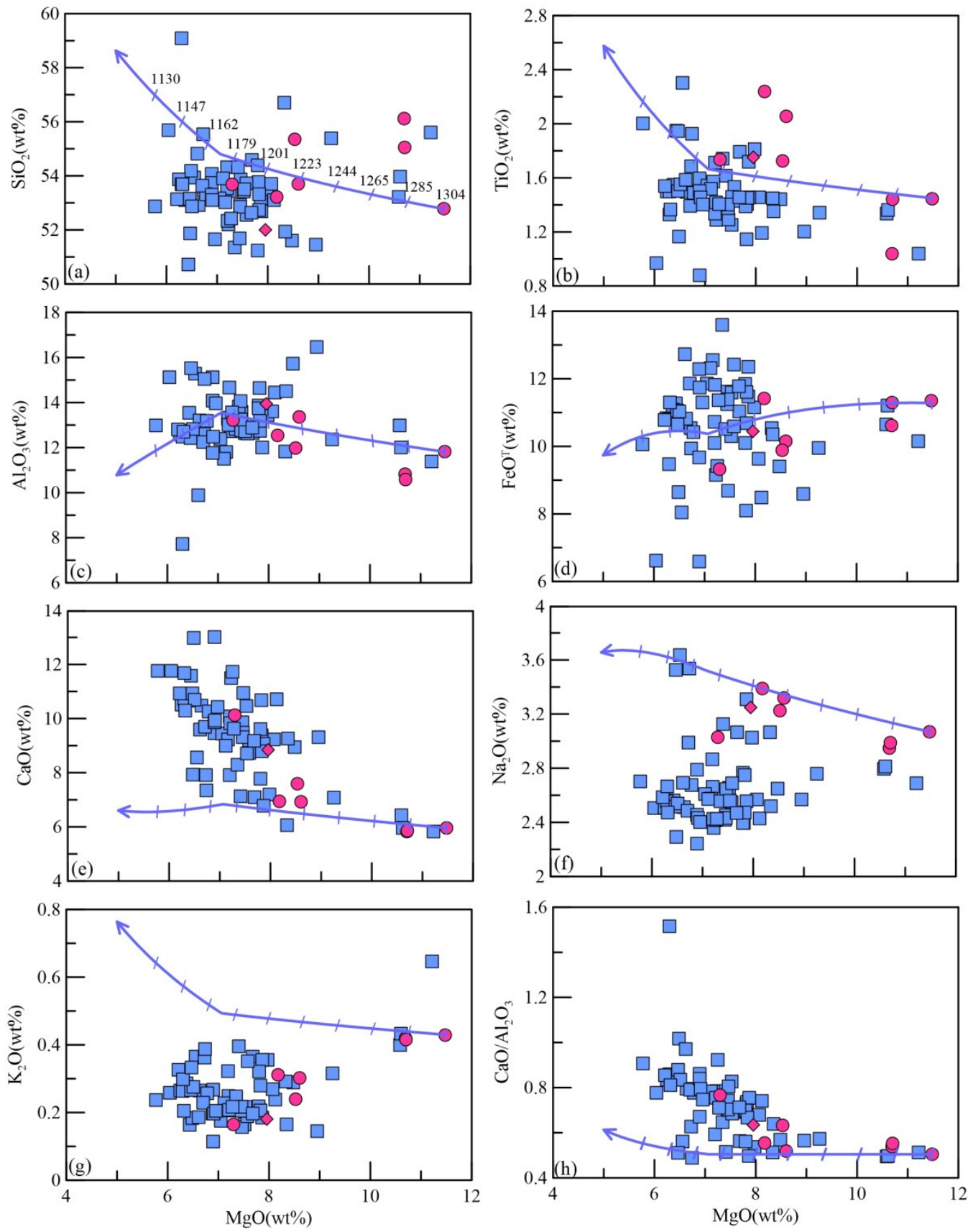

Figure 9. Plots of $\mathrm{MgO}$ versus (a) $\mathrm{SiO}_{2}$, (b) $\mathrm{TiO}_{2}$, (c) $\mathrm{Al}_{2} \mathrm{O}_{3}$, (d) $\mathrm{FeO}^{\mathrm{T}}$, (e) $\mathrm{CaO}$, (f) $\mathrm{Na}_{2} \mathrm{O}$, (g) $\mathrm{K}_{2} \mathrm{O}$ and (h) $\mathrm{CaO} / \mathrm{Al}_{2} \mathrm{O}_{3}$ of basaltic rocks from Sites U1381 and U1414. The liquid line of descent (LLD) was calculated under an ideal fractional crystallization at the pressure of $1.0 \mathrm{GPa}$ and anhydrous conditions by using the Petrolog3 software [29], and $\mathrm{Fe}_{2} \mathrm{O}_{3}$ in the melt was calculated using QFM buffer of oxygen fugacity. Sample 334-U1381A-26R-1-W 80/83 with highest $\mathrm{MgO}$ of $11.5 \mathrm{wt} \%$ was selected as starting material [18]. Note that when changing the modeling pressure to 0.1 and/or 0.5 GPa, the curves are almost the same. The numbers near the LLD curves indicate the temperatures. The selected minerals involved in crystallization differentiation were olivine (ol), clinopyroxene (cpx), plagioclase (pl) and magnetite (mgt), and modeling results have been presented in Supplementary Table S8. Symbols and data sources are the same as Figure 7. 
Table 1. Crystallization temperatures/pressures of plagioclases and clinopyroxenes in basaltic rocks from Sites U1381 and U1414. Note that the values of T1 and P1 were calculated by using the method of Putirka et al. (1996), and those for T2 and P2 were calculated by using the method of Putirka (2008).

\begin{tabular}{|c|c|c|c|c|c|c|c|c|c|c|c|c|c|}
\hline \multirow{3}{*}{ Hole } & \multirow{3}{*}{ Occurrence } & \multicolumn{4}{|c|}{ Plagioclase T/P Calcualtion } & \multicolumn{8}{|c|}{ Clinopyroxene T/P Calculation } \\
\hline & & \multicolumn{2}{|c|}{$\begin{array}{l}\text { Plagioclase-Melt } \\
\text { Thermometers of Mathez } \\
\text { (1973); SD = } 34{ }^{\circ} \mathrm{C}\end{array}$} & \multicolumn{2}{|c|}{$\begin{array}{l}\text { REE-in-Plagioclase } \\
\text {-Clinopyroxene } \\
\text { Geothermometer of Sun } \\
\text { and Liang (2017) }\end{array}$} & \multicolumn{4}{|c|}{$\begin{array}{c}\text { Clinopyroxene-Liquid } \\
\text { Thermobarometer (Eqn. T2 and Eqn. } \\
\text { P1 of Putirka et al., 1996); SEE } \\
T= \pm 52{ }^{\circ} \text {; SEE } P= \pm 0.46 \text { Gpa }\end{array}$} & \multicolumn{4}{|c|}{$\begin{array}{l}\text { Clinopyroxene Thermobarometer (Eqn. } \\
\text { 32a and Eqn. 32d of Putirka, 2008); SEE } \\
\quad \mathrm{T}= \pm 58{ }^{\circ} \mathrm{C} \text {; SEE } \mathrm{P}= \pm 0.31 \mathrm{Gpa}\end{array}$} \\
\hline & & $\mathrm{T}\left({ }^{\circ} \mathrm{C}\right)$ & $1 \sigma$ & $\mathrm{T}\left({ }^{\circ} \mathrm{C}\right)$ & $P(G P a)$ & $\mathrm{T} 1\left({ }^{\circ} \mathrm{C}\right)$ & $1 \sigma$ & P1 (GPa) & $1 \sigma$ & $\mathrm{T} 2\left({ }^{\circ} \mathrm{C}\right)$ & $1 \sigma$ & P2 (GPa) & $1 \sigma$ \\
\hline \multirow{2}{*}{ U1381A } & Phenocryst & $\begin{array}{c}1050-1215 \\
(n=14)\end{array}$ & 55 & $\begin{array}{c}1268 \\
(n=1)\end{array}$ & $\begin{array}{c}0.7 \\
(n=1)\end{array}$ & $\begin{array}{c}1213-1268 \\
(n=5)\end{array}$ & 19 & $\begin{array}{c}0.55-0.97 \\
(n=5)\end{array}$ & 0.15 & $\begin{array}{c}1205-1254 \\
(n=5)\end{array}$ & 16 & $\begin{array}{c}0.46-0.79 \\
(n=5)\end{array}$ & 0.11 \\
\hline & $\begin{array}{c}\text { Microlite/ } \\
\text { mircophenocrysts }\end{array}$ & $\begin{array}{l}866-988 \\
(n=17)\end{array}$ & 40 & $\begin{array}{c}1047 \\
(n=1)\end{array}$ & & $\begin{array}{c}1187-1261 \\
(n=10)\end{array}$ & 27 & $\begin{array}{c}0.23-0.93 \\
(n=10)\end{array}$ & 0.23 & $\begin{array}{c}1170-1239 \\
(n=10)\end{array}$ & 22 & $\begin{array}{c}0.02-0.66 \\
(n=10)\end{array}$ & 0.20 \\
\hline \multirow{2}{*}{ U1381C } & Phenocryst & $\begin{array}{c}1166-1242 \\
(n=3)\end{array}$ & 34 & $\begin{array}{c}1177 \\
(n=1)\end{array}$ & $\begin{array}{c}0.4 \\
(n=1)\end{array}$ & $\begin{array}{c}1174-1187 \\
(n=2)\end{array}$ & 6 & $\begin{array}{c}0.22-0.39 \\
(n=2)\end{array}$ & 0.08 & $\begin{array}{c}1185-1217 \\
(n=4)\end{array}$ & 12 & $\begin{array}{c}0.20-0.35 \\
(n=4)\end{array}$ & 0.06 \\
\hline & $\begin{array}{l}\text { Microlite/ } \\
\text { mircophenocrysts }\end{array}$ & $\begin{array}{c}1021-1032 \\
(n=3)\end{array}$ & 4 & $\begin{array}{c}1145 \\
(n=1)\end{array}$ & & $\begin{array}{c}1192-1198 \\
(n=2)\end{array}$ & 3 & $\begin{array}{c}0.43-0.47 \\
(n=2)\end{array}$ & 0.02 & $\begin{array}{c}1191-1195 \\
(n=2)\end{array}$ & 2 & $\begin{array}{c}0.34-0.63 \\
(n=2)\end{array}$ & 0.15 \\
\hline \multirow{2}{*}{ U1414A } & Phenocryst & $\begin{array}{c}1056-1269 \\
(n=59)\end{array}$ & 40 & $\begin{array}{c}1186-1250 \\
(n=2)\end{array}$ & $\begin{array}{l}0.3-0.4 \\
(n=2)\end{array}$ & $\begin{array}{c}1178-1209 \\
(n=13)\end{array}$ & 9 & $\begin{array}{c}0.12-0.50 \\
(n=13)\end{array}$ & 0.11 & $\begin{array}{c}1181-1215 \\
(n=13)\end{array}$ & 9 & $\begin{array}{c}0.27-0.44 \\
(n=13)\end{array}$ & 0.11 \\
\hline & $\begin{array}{c}\text { Microlite/ } \\
\text { mircophenocrysts }\end{array}$ & $\begin{array}{c}971-1038 \\
(n=18)\end{array}$ & 22 & $\begin{array}{c}1092-1166 \\
(n=6)\end{array}$ & & $\begin{array}{c}1162-1208 \\
(n=25)\end{array}$ & 13 & $\begin{array}{c}0.25-0.57 \\
(n=25)\end{array}$ & 0.10 & $\begin{array}{c}1135-1218 \\
(n=36)\end{array}$ & 17 & $\begin{array}{c}0.27-0.70 \\
(n=36)\end{array}$ & 0.12 \\
\hline
\end{tabular}

Note that " $n$ " in parentheses after calculating values refers to analytical numbers. 
In addition, the REE-in-plagioclase-clinopyroxene geothermometer of Sun and Liang [32] was also used to the crystallization pressures for these plagioclase phenocrysts/microlites. Note that the compositions of clinopyroxene microphenocrystals were used for the calculations of crystallization temperatures of plagioclase microlite population, and the pressure estimates were calculated by using the clinopyroxene thermobarometer of Putirka (33) (see below). The results show that the crystallization pressures of plagioclase phenocrysts (0.3-0.7 GPa) were slightly higher than those of the plagioclase microlites $(0.35-0.45 \mathrm{GPa})$, based on relatively limited analytical numbers (Table 1 ). In general, the calculating results of temperature/pressures is consistent with the inferred crystallization sequence of plagioclase phenocrysts and microlites in earlier and later stages of the evolving magmas, respectively.

\section{Crystallization Temperatures and Pressures of Clinopyroxenes}

Previous studies showed that one can infer the genetic relationship between the minerals and the host magma, and acquire important information about magmatic evolution [33,34]. Moreover, using the partition coefficients of trace elements between crystals and melt, the composition of parental melts can be calculated [35]. Fe-Mg exchange coefficients $\left(\mathrm{K}_{\mathrm{D}}\right)$ presented by Putirka [34] and $(\mathrm{FeO} / \mathrm{MgO})_{\text {host magma }}\left(\mathrm{as}(\mathrm{FeO} / \mathrm{MgO})_{\text {liq }}\right.$ ) values can be used to test whether clinopyroxene were in an equilibrium with melt. In this study, except for few phenocrysts, most of the clinopyroxenes are in equilibrium with the melt that is represented by bulk-rock compositions of Cocos ridge basement basaltic rocks (Figure 10). In this study, we used the clinopyroxene/melt distribution coefficients [27] (Supplementary Table S6) and the REE contents of the clinopyroxenes, in order to calculate the REE contents of the parental melts in equilibrium with the clinopyroxene. The results of the calculation are presented in Supplementary Table S9. We compare the calculated results and the host basalt (Supplementary Table S7) as shown in Figure 11, which shows that the calculated parental magma and the host basaltic rocks of clinopyroxenes have similar subparallel chondrite-normalized REE patterns, characterized by slight enrichment of LREE over MREE and HREE. In particular, the compositions of parental magmas calculated for the clinopyroxene phenocrysts are similar to those of host basaltic rocks and are slightly lower than those calculated for the clinopyroxene microlites (Supplementary Table S9). Because REE are incompatible, they are enriched in the residual melt in response to a fractional crystallization process. This is consistent with the results obtained by the higher REE contents of the microlites (crystallized from evolved magma at a later stage), relative to relatively low REE contents of the phenocrysts (crystallized from relatively primitive magma at an earlier stage).

Based on a study of plume-influenced mid-ocean-ridge basalts, Dixon et al. [36] proposed that the $\mathrm{H}_{2} \mathrm{O} / \mathrm{Ce}$ ratio of DMM (depleted MORB mantle) is 200, while the $\mathrm{H}_{2} \mathrm{O} / \mathrm{Ce}$ of the EM (enriched mantle) source mantle is lower than 100. The mantle source for the Cocos Ridge basement rocks drilled at IODP Sites U1381 and U1414 may be a PLUME mantle source (see discussion above), possibly consisting of DMM and EM2 [18]. The average Ce content of the basalts is only $1.01 \mathrm{ppm}$, implying that the magma system may have a low content of $\mathrm{H}_{2} \mathrm{O}$. Therefore, in this study host basaltic rocks (as liquid in the calculation) were presumed to be water-free, and we calculated the crystallization temperatures and pressures of the clinopyroxenes using a water-free clinopyroxene-liquid thermobarometer (Equation (T2) and Equation (P1) of [33]). For comparison, a clinopyroxene thermobarometer (Equation (32) and Equation (32d) of [34]) was also used, and note that the thermobarometer was developed by using only clinopyroxene compositions. The results calculated by these two calibrations are relatively consistent with each other (Table 1 , Figure 12). Based on the discussions above, we adopted the results calculated from a waterfree clinopyroxene-liquid thermobarometer [33]. According to the thermobarometer, the range of crystallization temperature of clinopyroxene phenocrysts is $1162-1268^{\circ} \mathrm{C}$, and that for the equilibrium pressure is $0.12-0.97 \mathrm{GPa}$ (corresponding to depths of $4.7-36.7 \mathrm{~km}$ ) (Table 1). In addition, estimates from the clinopyroxene thermobarometer [34] show that 
the temperatures and pressures of clinopyroxenes are $1135-1154{ }^{\circ} \mathrm{C}$ and $0.02-0.79 \mathrm{GPa}$, respectively (Table 1). Considering there existed the errors for these two calculation methods, we suggested that the temperatures and pressures of clinopyroxenes are $1135-1268{ }^{\circ} \mathrm{C}$, and 0.02-0.97 GPa, respectively, and there also existed some differences in estimates among different drilling holes (U1381A, U1381C and U1414A) (Table 1). In addition, similar to the case of Cocos ridge basalts produced by Galapagos plume in this study, some previous studies show there also exised a polybaric crystallization (1.0 to $0.1 \mathrm{GPa}$ ) of clinopyroxene in plume-related basalts $[37,38]$.

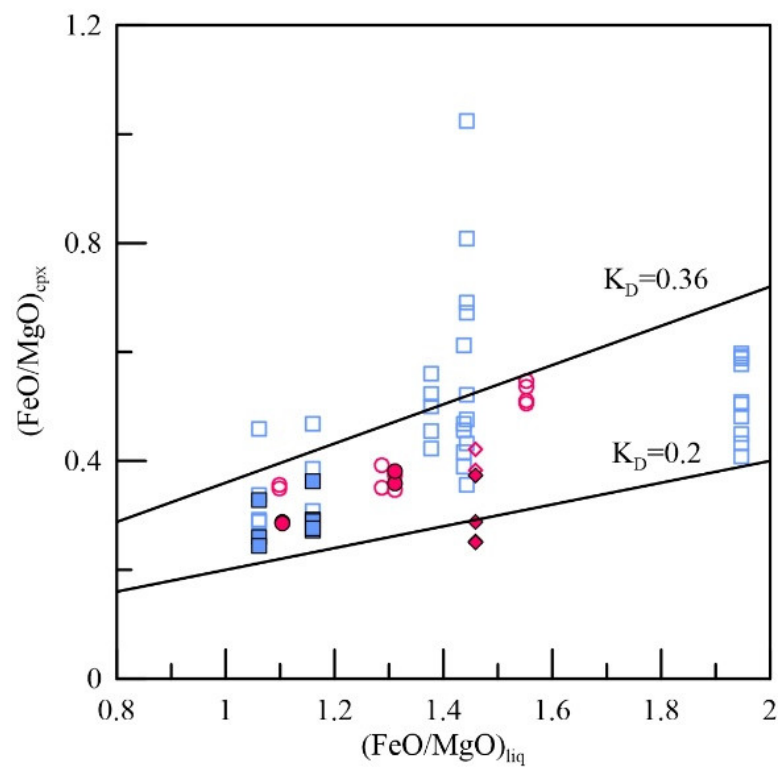

Figure 10. $(\mathrm{FeO} / \mathrm{MgO})_{\mathrm{liq}}-(\mathrm{FeO} / \mathrm{MgO})_{\mathrm{cpx}}$ diagram for clinopyroxenes (Putirka, 2008). $\mathrm{K}_{\mathrm{D}}(\mathrm{Fe}-$ $\mathrm{Mg})_{\mathrm{cpx}-\mathrm{liq}}=(\mathrm{FeO} / \mathrm{MgO})_{\mathrm{cpx}} /(\mathrm{FeO} / \mathrm{MgO})_{\text {liq. }}$. When $\mathrm{K}_{\mathrm{D}}=0.28 \pm 0.08$, clinopyroxene and melt reached equilibrium [34]. Symbols are the same as Figure 6.

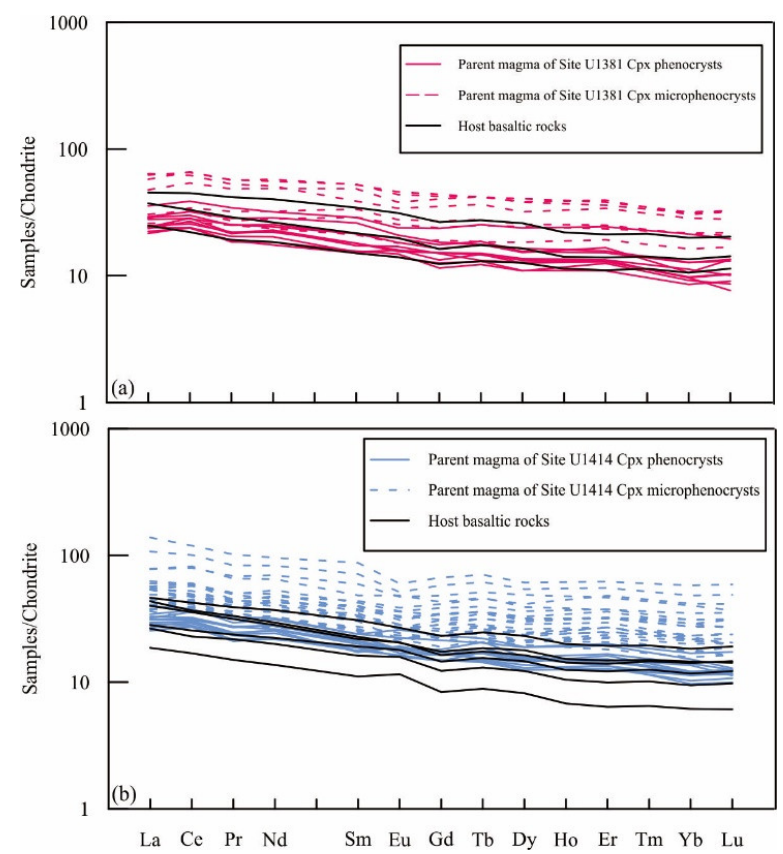

Figure 11. Chondrite-normalized REE distributional diagram of parent magmas inferred from the clinopyroxene compositions. (a) site U1381, (b) site U1414. For the purse of comparison, bulk basaltic rocks from Sites U1381 and U1414 [18] are also plotted. Data for chondrite are from [24]. 

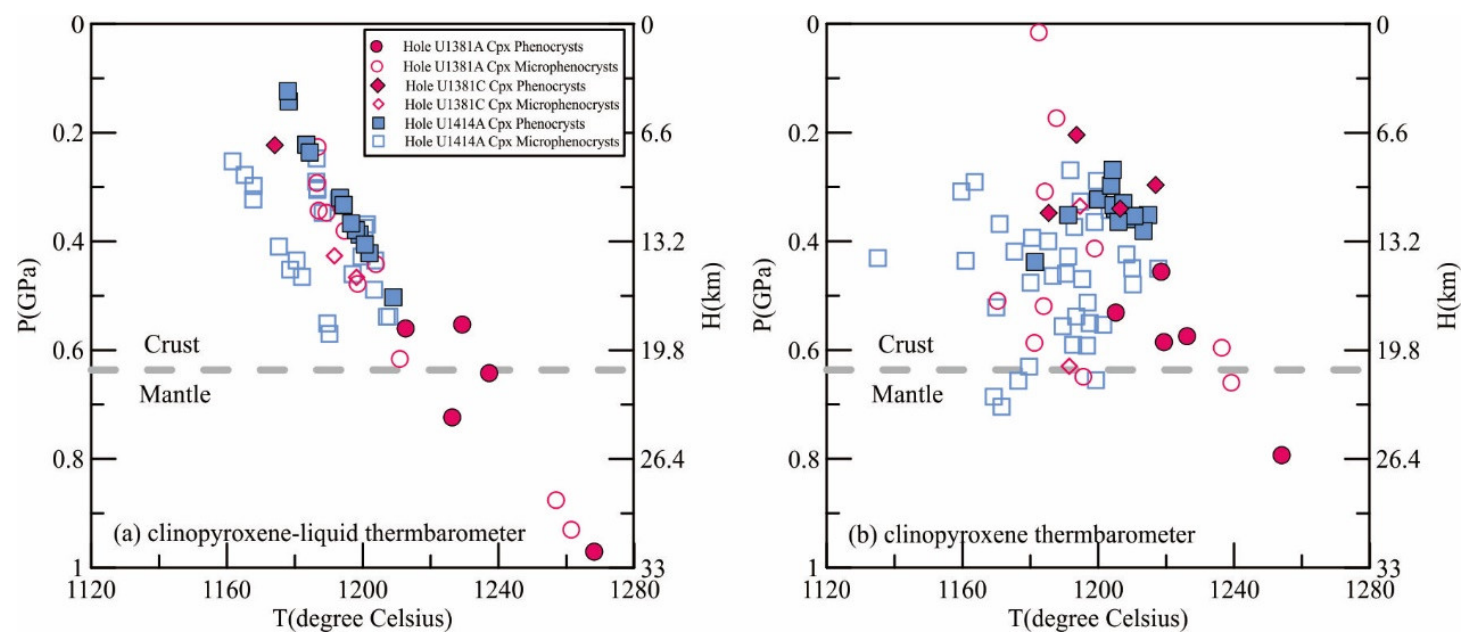

Figure 12. Pressures and temperatures of clinopyroxenes of basaltic rocks from Sites U1381 and U1414. (a) clinopyroxeneliquid thermbarometer, $(\mathbf{b})$ clinopyroxene thermbarometer. The dotted gray line represents the line between crust and the lithospheric mantle. The pressure gradient of average lithosphere is $0.033 \mathrm{GPa} / \mathrm{km}$.

The crystallization temperatures of clinopyroxene phenocrysts/micro-phenocrysts $\left(1174-1268^{\circ} \mathrm{C}\right)$ are similar to those of plagioclase phenocrysts $\left(1050\right.$ to $\left.1269^{\circ} \mathrm{C}\right)$ (Table 1$)$, suggesting that during the early stage of magmatic evolution, some of clinopyroxene and plagioclase phenocrysts cotectic crystallized, as petrographic characteristics (glomerophyric textures formed by clinopyroxene and plagioclase phenocrysts) shown (Figure 2). In addition, a small amount of clinopyroxenes show no negative Eu anomaly (Figure 6) and have higher crystallization pressures (up to $0.97 \mathrm{GPa}$ ) (Table 1), implying that they may be crystallized earlier than plagioclase and reflecting that their parental magmas were produced by partial melting of upper mantle rocks. Walther [4] reported that the crustal thickness in the central part of the Cocos Ridge is about $25 \mathrm{~km}$, greater than three times normal oceanic crustal thickness. The overthickened Cocos ridge [19-21] may experience a more complex magmatic process relative to adjacent mid-oceanic ridge (e.g., East Pacific Rise). Based on the above discussions, we suggest that parental magma of basaltic rocks from the Cocos ridge in this study was derived from upper mantle, and the clinopyroxene crystallized continuously during the melt ascent from the upper mantle to the surface, as estimates for equilibrium pressures of clinopyroxenes shown in Figure 12. The implications of this study that the Cocos ridge related to Galapagos plume/hotspot has anomalous thick crust, but parental magmas of Cocos ridge basalts were originated from the upper mantle level.

\section{Conclusions}

In this study, we carried out in situ major- and trace element analysis of plagioclases and clinopyroxenes of Cocos Ridge basaltic rocks from IODP Sites U1381 and U1414, and obtained some new insights as follows:

(1) Basaltic lavas of Cocos Ridge from Sites U1381 and U1414 were produced by 1-5\% melting of a PLUME mantle source. The parental magmas of clinopyroxene, inferred from clinopyroxene compositions, have similar REE distributional patterns to their host basaltic rocks, implying that clinopyroxenes were crystallized from parental magmas of their host basaltic rocks, not xenocrysts. During its ascent to the surface, the parental magma underwent extensive fractional crystallization of minerals (e.g., clinopyroxene, olivine, plagioclase, Fe-Ti oxides, etc.), as illustrated by plots of $\mathrm{Mg}^{\sharp} \mathrm{Cpx}$ versus oxides (Figure 8).

(2) The crystallization temperatures of plagioclase phenocrysts and microlites are 1050 to 1269 , and 866 to $1038^{\circ} \mathrm{C}$, which reflected that plagioclase phenocrysts and microlites were crystallized in the earlier and later stages of the evolving magmas, respectively. 
(3) The crystallization temperature range of clinopyroxene phenocrysts/microphenocrysts is $1162-1268^{\circ} \mathrm{C}$, similar to those of plagioclase phenocrysts $\left(1050\right.$ to $\left.1269^{\circ} \mathrm{C}\right)$, suggesting some of clinopyroxene and plagioclase phenocrysts cotectic crystallized during early stage of magmatic evolution. A small amount of clinopyroxenes with no negative Eu anomaly and highest crystallization pressures $(>0.7 \mathrm{GPa})$ may be crystallized earlier than plagioclases phenocrysts with crystallization pressures of $0.3-0.7 \mathrm{GPa}$, reflecting that there existed a crystallization with clinopyroxene and no plagioclase. The equilibrium pressure of one clinopyroxene phenocryst is up to $0.97 \mathrm{GPa}$ (corresponding to depth of about $36.7 \mathrm{~km}$ ), implying the clinopyroxene started to crystallize within the mantle.

Supplementary Materials: The following are available online at https:/ / www.mdpi.com/article / $10.3390 / \min 11070769 / \mathrm{s} 1$, Table S1: Summary of three drilling holes on incoming Cocos ridge collected during IODP Expeditions 334 and 344, Table S2: Major oxides compositions (wt.\%) of plagioclases in basaltic rocks from Sites U1381 and U141., Table S3: Trace element compositions (ppm) of plagioclases in basaltic rocks from Sites U1381 and U1414, Table S4: Major oxides compositions (wt.\%) of clinopyroxenes in basaltic rocks from Sites U1381 and U1414, Table S5: Trace element compositions (ppm) of clinopyroxene in basaltic rocks from the Cocos Ridge, Table S6: Distribution coefficients between clinopyroxene and melt, Table S7: Major- and trace elements of basaltic rocks from the Cocos Ridge, Table S8: Modeling results of mineral crystallization for Cocos basaltic rocks, Table S9: REE contents of the calculated parent melts balanced with the clinopyroxenes in basaltic rocks from the Cocos Ridge.

Author Contributions: Q.Y. and Z.G., conceived the experiments, conducted the experiments, analyzed data, wrote the manuscript, contributed to interpretive aspects, and reviewed the manuscript. All authors have read and agreed to the published version of the manuscript.

Funding: This work was supported by National Key Research and Development Program of China (2017YFC1405502), National Natural Science Foundations of China (Grant Numbers 41776070, 41322036, 41276003), and Taishan Scholarship from Shandong Province.

Institutional Review Board Statement: Not applicable.

Informed Consent Statement: Not applicable.

Data Availability Statement: Some of the data presented in this study are available in the Supplementary Materials, Tables S1-S9.

Acknowledgments: We are grateful to four anonymous reviewers for their helpful comments, and Susanne Straub for reviewing the original manuscript, Ruiping Quan for LA-ICP-MS analyses, and Meijuan Shi for EPMA analyses. The samples and data of this research are provided by the International Ocean Discovery Program (IODP). We thank the outstanding efforts of the Siem Offshore officers and crew as well as the drilling personnel and the scientific parties of IODP Expeditions 334 and 344, and IODP-China.

Conflicts of Interest: The authors declare no conflict of interest.

\section{References}

1. Morgan, W.J. Convection plumes in the lower mantle. Nature 1971, 230, 42-43. [CrossRef]

2. Werner, R.; Hoernle, K.; Paul, V.; Ranero, C.; Von Huene, R.; Korich, D. Drowned 14-m.y.-old Galápagos archipelago off the coast of Costa Rica: Implications for tectonic and evolutionary models. Geology 1999, 27, 499-502. [CrossRef]

3. Huene, R.V.; Ranero, C.R.; Weinrebe, W.; Hinz, K. Quaternary convergent margin tectonics of Costa Rica, segmentation of the Cocos Plate, and Central American volcanism. Tectonics 2000, 19, 314-334. [CrossRef]

4. Walther, C. The crustal structure of the Cocos ridge off Costa Rica. J. Geophys. Res. Solid Earth 2003, 108, 2136. [CrossRef]

5. Geist, D.J.; White, W.; McBirney, A. Plume-asthenosphere mixing beneath the Galapagos archipelago. Nature 1988, 333, 657-660. [CrossRef]

6. White, W.; McBirney, A.; Duncan, R. Petrology and geochemistry of the Galápagos Islands: Portrait of a pathological mantle plume. J. Geophys. Res. Solid Earth 1993, 98, 19533-19563. [CrossRef]

7. Blichert-Toft, J.; White, W.M. Hf isotope geochemistry of the Galapagos Islands. Geochem. Geophys. Geosyst. 2001, 2. [CrossRef]

8. Harpp, K.S.; White, W.M. Tracing a mantle plume: Isotopic and trace element variations of Galápagos seamounts. Geochem. Geophys. Geosyst. 2001, 2. [CrossRef] 
9. Hoernle, K.; Werner, R.; Phipps Morgan, J.; Garbeschönberg, D.; Bryce, J.; Mrazek, J. Existence of complex spatial zonation in the Galápagos plume. Geology 2000, 28, 435-438. [CrossRef]

10. Gibson, S.A.; Geist, D. Geochemical and geophysical estimates of lithospheric thickness variation beneath Galápagos. Earth Planet. Sci. Lett. 2010, 300, 275-286. [CrossRef]

11. Harpp, K.S.; Weis, D. Insights into the origins and compositions of mantle plumes: A comparison of Galápagos and Hawaii. Geochem. Geophys. Geosyst. 2020, 21. [CrossRef]

12. Herzberg, C.; Gazel, E. Petrological evidence for secular cooling in mantle plumes. Nature 2009, 458, 619-622. [CrossRef] [PubMed]

13. Johnston, S.; Thorkelson, D. Cocos-Nazca slab window beneath Central America. Earth Planet. Sci. Lett. 1997, 146, 465-474 [CrossRef]

14. Werner, R.; Hoernle, K.; Barckhausen, U.; Hauff, F. Geodynamic evolution of the Galápagos hot spot system (Central East Pacific) over the past 20 m.y.: Constraints from morphology, geochemistry, and magnetic anomalies. Geochem. Geophys. Geosyst. 2003, 4, 1108. [CrossRef]

15. Harpp, K.; Wanless, V.; Otto, R.; Hoernle, K.; Werner, R. The Cocos and Carnegie Aseismic Ridges: A trace element record of long-term plume-spreading center interaction. J. Petrol. 2005, 46, 109-133. [CrossRef]

16. Gazel, E.; Trela, J.; Bizimis, M.; Sobolev, A.; Batanova, V.; Class, C.; Jicha, B. Long-lived source heterogeneities in the Galapagos Mantle Plume. Geochem. Geophys. Geosyst. 2018, 19, 2764-2779. [CrossRef]

17. Trela, J.; Vidito, C.; Gazel, E.; Herzberg, C.; Class, C.; Whalen, W.; Jicha, B.; Bizimis, M.; Alvarado, G. Recycled crust in the Galápagos Plume source at 70 Ma: Implications for plume evolution. Earth Planet. Sci. Lett. 2015, 425, 268-277. [CrossRef]

18. Yan, Q.; Shi, X. Data report: Major and trace element and Sr-Nd-Pb isotope analyses for basement rocks from the CRISP-A transect drilled during expeditions 334 and 344. Proceedings of the Integrated Ocean Drilling Program, College Station, TX (Integrated Ocean Drilling Program). 2016. Available online: http://publications.iodp.org/proceedings/344/344toc.htm\#Expedition_research_ results (accessed on 15 March 2020).

19. Vannucchi, P.; Ujiie, K.; Stroncik, N.; Malinverno, A. Expedition 334 Scientists. Proceedings of the IODP, 334: Tokyo (Integrated Ocean Drilling Program Anagement International, Inc.). 2012. Available online: http://publications.iodp.org/proceedings/334/334toc. htm\#Expedition_research_results (accessed on 15 March 2020). [CrossRef]

20. Harris, R.N.; Sakaguchi, A.; Petronotis, K. Input Site U1381. Proceedings of the Integrated Ocean Drilling Program, College Station, TX (Integrated Ocean Drilling Program). Harris, R.N., Sakaguchi, A., Petronotis, K., The Expedition 344 Scientists, Eds.; 2013. Available online: http:/ / publications.iodp.org/proceedings/344/103/103_htm (accessed on 15 March 2020).

21. Harris, R.N.; Sakaguchi, A.; Petronotis, K. Proceedings of the Integrated Ocean Drilling Program, College Station, TX (Integrated Ocean Drilling Program). 2013. Available online: http://publications.iodp.org/proceedings/344/344toc.htm\#Expedition_research_ results (accessed on 15 March 2020).

22. Brandstätter, J.; Kurz, W.; Richoz, S.; Cooper, M.; Teagle, D. The Origin of Carbonate Veins within the Sedimentary Cover and Igneous Rocks of the Cocos Ridge: Results from IODP Hole U1414A. Geochem. Geophys. Geosyst. 2018, 19, 3721-3738. [CrossRef]

23. Li, Y.; Zhao, X.; Jovane, L.; Petronotis, K.; Gong, Z.; Xie, S. Paleomagnetic constraints on the tectonic evolution of the Costa Rican subduction zone: New results from sedimentary successions of IODP drill sites from the Cocos Ridge. Geochem. Geophys. Geosyst. 2015, 16, 4479-4493. [CrossRef]

24. Sun, S.; McDonough, W. Chemical and isotopic systematics of oceanic basalts: Implications for mantle composition and processes. Geol. Soc. Lond. Spec. Publ. 1989, 42, 313-345. [CrossRef]

25. Morimoto, N. Nomenclature of pyroxenes. Am. Mineral. 1988, 73, 1123-1133.

26. Bédard, J. Parameterizations of calcic clinopyroxene-Melt trace element partition coefficients. Geochem. Geophys. Geosyst. 2014, 15, 303-336. [CrossRef]

27. Hart, S.; Dunn, T. Experimental cpx/melt partitioning of 24 trace elements. Contrib. Mineral. Petrol. 1993, 113, 1-8. [CrossRef]

28. Wang, X.; Li, Z.; Li, X.; Li, J.; Liu, Y.; Long, W.; Zhou, J.; Wang, F. Temperature, Pressure, and Composition of the Mantle Source Region of Late Cenozoic Basalts in Hainan Island, SE Asia: A Consequence of a Young Thermal Mantle Plume close to Subduction Zones? J. Petrol. 2012, 53, 177-233. [CrossRef]

29. Danyushevsky, L.; Plechov, P. Petrolog3: Integrated software for modeling crystallization processes. Geochem. Geophys. Geosyst. 2011, 12, Q07021. [CrossRef]

30. Mathez, E. Refinement of the Kudo-Weill plagioclase thermometer and its application to basaltic rocks. Contrib. Mineral. Petrol. 1973, 41, 61-72. [CrossRef]

31. Putirka, K.D. Igneous thermometers and barometers based on plagioclase + liquid equilibria: Tests of some existing models and new calibrations. Am. Mineral. 2005, 90, 336-346. [CrossRef]

32. Sun, C.; Liang, Y. A REE-in-plagioclase-clinopyroxene thermometer for crustal rocks. Contrib. Mineral. Petrol. 2017, 172. [CrossRef]

33. Putirka, K.; Johnson, M.; Kinzler, R.; Longhi, J.; Walker, D. Thermobarometry of mafic igneous rocks based on clinopyroxene-liquid equilibria, 0-30 kbar. Contrib. Mineral. Petrol. 1996, 123, 92-108. [CrossRef]

34. Putirka, K. Thermometers and Barometers for Volcanic Systems. Rev. Mineral. Geochem. 2008, 69, 61-120. [CrossRef]

35. Woodland, A.; Jugo, P. A complex magmatic system beneath the Devès volcanic field, Massif Central, France: Evidence from clinopyroxene megacrysts. Contrib. Mineral. Petrol. 2007, 153, 719-731. [CrossRef] 
36. Dixon, J.; Leist, L.; Langmuir, C.; Schilling, J. Recycled dehydrated lithosphere observed in plume-influenced mid-ocean-ridge basalt. Nature 2002, 420, 385-389. [CrossRef] [PubMed]

37. Stock, M.; Bagnardi, M.; Neave, D.; Maclennan, J.; Bernard, B.; Buisman, I.; Gleeson, M.; Geist, D. Integrated Petrological and Geophysical Constraints on Magma System Architecture in the Western Galapagos Archipelago: Insights from Wolf Volcano. Geochem. Geophys. Geosyst. 2018, 19, 4722-4743. [CrossRef]

38. Winpenny, B.; Maclennan, J. A partial record of mixing of mantle melts preserved in Icelandic phenocrysts. J. Petrol. 2011, 52, 1791-1812. [CrossRef] 